\title{
Mortgage Bank Refinancing - Proposals for Implementation of the European Covered Bond Directive in Hungary*
}

\author{
Gyula László Nagy-Zsombor Incze - Erik Landgraf
}

In this study, we summarise the operational models of mortgage banks and the new EU mortgage bond regulations. We analyse the most important challenges facing refinancing mortgage banks in the current framework. These are basically grouped into three subjects: (1) for historical reasons, the characteristics of refinancing loans do not support more efficient portfolio refinancing; (2) the refinancing loan guarantee scheme does not ensure fulfilment of the conditions laid down in other legislation in case of statutory portfolio assignment; (3) overcollateralisation in the current purely refinancing model cannot be achieved from ordinary collateral. On this basis, we propose the development of an alternative regulation for "refinancing mortgage banks", while fully maintaining the current operation; with this alternative regulation, a revised collateral system would help to solve the problems and develop a more efficient mortgage loan structure.

Journal of Economic Literature (JEL) codes: G28, G21, K22, K23

Keywords: covered bonds, mortgage banks, mortgage bonds, mortgage loans, refinancing

\section{Introduction}

One of the defining events in the history of consumer mortgage lending in Hungary in the period following the conversion of foreign currency loans into forints was the introduction of the Mortgage Funding Adequacy Ratio. This regulatory step also marked the future direction of mortgage banks' business operations, in which refinancing activities became dominant. At the end of 2019, on the occasion of

* The papers in this issue contain the views of the authors which are not necessarily the same as the official views of the Magyar Nemzeti Bank.

Gyula László Nagy is the Chief Executive Officer of Takarék Mortgage Bank. Email: Nagy.GyulaLaszlo@takarek.hu Zsombor Incze is a Project Manager of Takarék Mortgage Bank for Renewal of Refinancing Project.

Email: Incze.Zsombor@takarek.hu

Erik Landgraf Attorney-at-Law at Szabó Kelemen \& Andersen Attorneys (previously Senior Legal Counsel of Takarék Mortgage Bank). Email: erik.landgraf@hu.AndersenLegal.com

The study contains the views of the authors, which are not necessarily the same as the official views of Takarék Mortgage Bank Plc.

The Hungarian manuscript was received on 17 March 2020.

DOI: http://doi.org/10.33893/FER.19.3.102129 
the 250th anniversary of the creation of the mortgage bond, the VDP (Association of German Pfandbrief Banks) held a large-scale celebration in Berlin. After long preparations and extensive negotiations, exactly 250 years earlier Prussian Emperor Frederick II announced the creation of the first mortgage bond and promulgated a decree allowing the first successful issuance of a Pfandbrief, which significantly contributed to the consolidation of Prussia's financial situation at the time. The first mortgage bond programme was followed by successful issuance in other European countries in the $19^{\text {th }}$ and $20^{\text {th }}$ centuries. The success story of mortgage bonds or covered bonds as they are currently known continues to this day. Over the past 20 years, covered bond volumes have grown dynamically. According to Kullig et al. (2019), at the end of 2018, the total stock on the European capital market amounted to EUR 2,600 billion. This represents the second largest market for investors after the government securities market.

In Hungary, mortgage bonds began to be issued in the 1840s. The history of mortgage bond-based financing is elaborated in more detail by Kovács (2004). Following the political transition, Act XXX of 1997 (hereinafter: Jht.) established the operating framework of the current mortgage banks, which, in addition to Kovács (2004), was also presented by Vincze (2002) and Király - Nagy (2008) for example, while Fóriánné Horváth (2019) summarized it comprehensively. The event with the greatest impact on mortgage bank operations in recent years was the introduction of the Mortgage Funding Adequacy Ratio (MFAR) announced by the Magyar Nemzeti Bank (MNB) in 2015 (MNB 2015) and introduced on 1 October 2016, which brought about the appearance of two new mortgage banks (Erste Mortgage Bank, K\&H Mortgage Bank) and also laid out the new role of these specialised institutions for the long-term. The impacts of the MFAR regulation on the banking system, the size of new issuances induced by the regulation and the investors' profile was presented by $M N B$ (2016), MNB (2017) and MNB (2018) in details.

In this article, we present the operating models of mortgage banks, as well as the separate parts of the new EU mortgage bond regulation and its highlights included in the CRR (Capital Requirements Regulation, (EU) No 575/2013 of the European Parliament on prudential requirements for credit institutions and investment firms, EU 2013). Following this, we analyse the main aspects of the current Hungarian operating model, highlighting the structural challenges, for which we propose solutions (following the example of the European and the Swiss mortgage banking systems). Implementation of our proposals may become possible with the domestic implementation of the new EU directive. We also aim to initiate a professional dialogue on efficiency issues that can be addressed by fine-tuning the regulatory environment. Remedying these can simultaneously improve the situation for both mortgage bond investors and mortgage loan borrowers. 


\section{Mortgage bank operating models}

\subsection{Overview}

Before examining Directive (EU) 2019/2162 (EU 2019a, hereinafter: the Directive) and the related CRR modification Regulation (EU) No 2019/2160 (EU 2019b, hereinafter: CRR Amendment) in detail, let us outline some of the Member State models operating within the scope of these regulatory instruments. One of the most significant summaries on the topic in recent years was written by Stöcker (2011), who has been engaged with the topic for a long time. Although it is difficult to arrange each model according to uniform criteria, Stöcker distinguishes five different mortgage bank operating models. Tóth (2017) provides a somewhat simpler summary using three different models, while Papp (2005) outlines four models using a different argumentation, which is also adopted by Fóriánné Horváth (2019). We summarise the findings of Stöcker (2011) in Table 1, supplemented with the statements of Tóth (2017).

\begin{tabular}{|c|c|c|c|c|c|}
\hline \multicolumn{6}{|c|}{$\begin{array}{l}\text { Table } 1 \\
\text { Mortgage bond financing - Five European models }\end{array}$} \\
\hline & Model 1 & Model 2 & Model 3 & Model 4 & Model 5 \\
\hline Legal Status & $\begin{array}{l}\text { Specialised } \\
\text { credit } \\
\text { institution }\end{array}$ & $\begin{array}{l}\text { Specialised } \\
\text { credit } \\
\text { institution }\end{array}$ & Universal bank & SPV* & $\begin{array}{l}\text { Specialised } \\
\text { credit } \\
\text { institution }\end{array}$ \\
\hline $\begin{array}{l}\text { Method of } \\
\text { financing }\end{array}$ & $\begin{array}{l}\text { Collateral } \\
\text { assets } \\
\text { acquisition } \\
\text { from parent } \\
\text { bank }\end{array}$ & $\begin{array}{l}\text { Loan } \\
\text { disbursement } \\
\text { to customers }\end{array}$ & $\begin{array}{l}\text { Loan } \\
\text { disbursement } \\
\text { to customers }\end{array}$ & $\begin{array}{l}\text { Collateral } \\
\text { assets } \\
\text { acquisition }\end{array}$ & $\begin{array}{l}\text { Legal transfer } \\
\text { of assets or } \\
\text { their liens }\end{array}$ \\
\hline $\begin{array}{l}\text { Implementing } \\
\text { countries } \\
\text { (partial list) }\end{array}$ & $\begin{array}{l}\text { Ireland, } \\
\text { Norway, } \\
\text { France, Finland, } \\
\text { Sweden }\end{array}$ & $\begin{array}{l}\text { Hungary, } \\
\text { Luxembourg, } \\
\text { Poland, } \\
\text { Denmark }\end{array}$ & \begin{tabular}{|l|} 
Austria, \\
Denmark, \\
Finland, \\
Germany, \\
Greece, Spain, \\
Portugal, Czech \\
Republic, \\
Slovakia
\end{tabular} & \begin{tabular}{|l} 
Italy, \\
Netherlands, \\
United \\
Kingdom
\end{tabular} & $\begin{array}{l}\text { Austria, France, } \\
\text { Denmark, } \\
\text { Germany, } \\
\text { Hungary, Spain, } \\
\text { Switzerland }\end{array}$ \\
\hline $\begin{array}{l}\text { Affected } \\
\text { domestic } \\
\text { mortgage } \\
\text { banks }\end{array}$ & & OTP & & & $\begin{array}{l}\text { Takarék, } \\
\text { UniCredit, K\&H, } \\
\text { Erste, OTP }\end{array}$ \\
\hline \multicolumn{6}{|c|}{ Note: * SPV - Special Purpose Vehicle } \\
\hline
\end{tabular}

Currently, Model 2 and 5 are active simultaneously in Hungary, but direct customer lending is only actively used by OTP Mortgage Bank (Model 2). 


\section{2. 'Pooling' model}

The logic of the pooling model is fundamentally based on the fact that the mortgage bond issuer raises a large amount of long-term funds on the capital markets and allocates this resource to the banks that originate mortgage loans and thus provide funding for it (Figure 1). The allocation mechanism can be extremely simple and straightforward (e.g. Switzerland) or it can take place through maturity or interest rate transformation (e.g. Hungary).

\section{Figure 1}

Structural operation of the pooling model

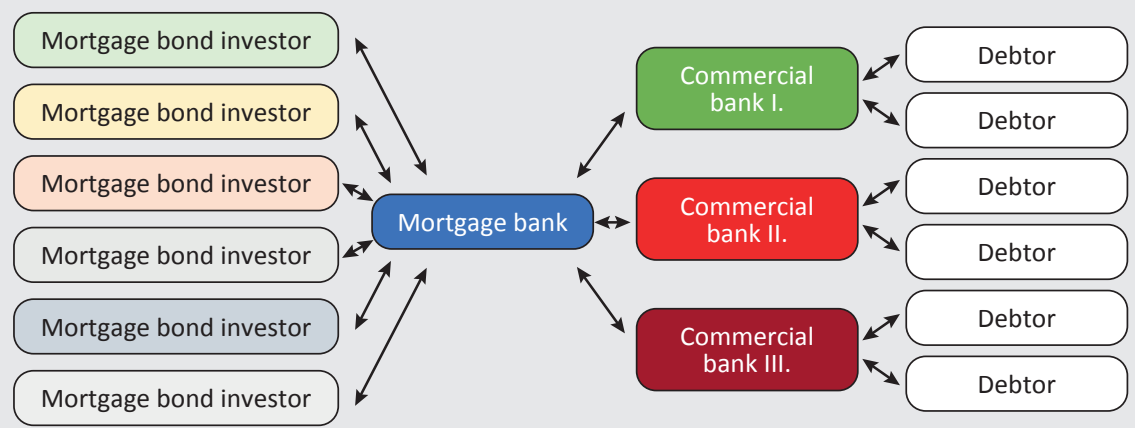

Source: Compiled based on Stöcker (2011:37)

According to Stöcker (2011), there are significant requirements for the smooth functioning of the pooling model. On the one hand, close cooperation between the refinancing mortgage bank and the refinanced commercial bank is essential to maintain the proper quality of the cover pool, and, on the other hand, an extremely strict and well-functioning legal mechanism is needed to maintain collateral coverage at all times.

According to Kemmish et al. (2017), this structure is used in many European countries in different regulatory frameworks that differ mainly in the identity of the issuer (specialised credit institution, universal bank or a special entity established by law). In Hungary, refinancing, which can also be described as a pooling model, also operates in a special structure, not used elsewhere, where refinancing takes place through the sale and simultaneous repurchase of independent mortgage liens.

\section{The new European covered bond regulation}

\subsection{Background}

With regard to covered bonds, the previous EU regulation was found in Article 52(4) of EC Directive 2009/65/EC (EC 2009), which sets out the general requirements for covered bonds. Article 129 of CRR added additional conditions to the above 
directive and allowed credit institutions to hold less capital when investing in covered bonds. As a result of this regulation, in the past, the conditions for investing in covered bonds can be considered harmonised within Member States, but there has been a lack of harmonisation at the EU level in terms of issuance conditions.

As a result of the review process launched in 2012 with the recommendation of the European Systemic Risk Board (ESRB 2012), a uniform new EU regulation of covered bonds was created by the end of 2019, which affected both the directive and the regulation. However, during the review, a basic principle remains unchanged in the current regulations: a covered bond can only be issued by a credit institution. This sets a clear line that separates these securities and their issuers from other securitisation operations regulated by Regulation (EU) 2017/2402 of the European Parliament and the Council (EU 2017). The purpose of the regulation is also unchanged: to regulate the conditions under which credit institutions may issue covered bonds as a financing instrument by establishing product requirements and specific product supervision for credit institutions in order to ensure a high level of investor protection.

As a result of several years of preparatory work, the European Covered Bond Directive (EU 2019a) was adopted and promulgated last year. Closely related to this, the CRR, regulation (EU) 2019/2160 on prudential requirements for credit institutions and was amended, which also means an obligation to adapt in Hungary. Mandatory implementation of the new Directive and the obligation to apply the CRR Amendment make it essential to review the existing domestic rules and adapt them to the constantly evolving market requirements. The new rules provide sufficient preparation time for both:

- the regulatory authorities of the Member States, with an implementation period of 18 months for the Directive until 8 July 2021,

- and market participants, which are given an additional 12 months to prepare,

and thus, the uniform starting date for application of the new rules will be 8 July 2022.

\subsection{Main provisions of the Directive}

The Directive sets out harmonised rules for covered bonds in Europe, building on elements of previous regulation. The basic pillars of the regulation are:

- dual recourse principle - according to which investors can enforce their claims against both the issuer of the covered bond and the cover assets;

- bankruptcy-remoteness principle - the enforcement of which guarantees that the insolvency or resolution of the issuer of the covered bonds will not result in the maturity of the mortgage bonds. 
The key areas of regulation of the Directive are:

\subsubsection{Collateral and liquidity rules}

One essential element of the covered bonds regulation is that it defines the rules for eligible cover, eligible collateral and their mandatory separation, that is, the rules for collateral registration. It is important to distinguish between a cover asset and a collateral asset, which are overlapping concepts. According to Article 3(4) of the Directive "'cover assets' means assets included in a cover pool", that is, exposures that have been placed using appropriate collateral. According to Article 3(5) "collateral assets' physical assets and assets in the form of exposures that secure cover assets" that are able to guarantee a high level of return on cover assets. With regard to the regulation of cover assets, it is important to emphasise that the Directive distinguishes between (i) loans secured by collateral assets and (ii) loans to or guaranteed by public undertakings. Among the loans secured by collateral assets, two subgroups have been regulated: loans that meet the strict requirements of the CRR Amendment (EU 2019b) and loans that meet the somewhat milder but still high-level requirements of the Directive (EU 2019a). The latter is also an important distinction because, along these lines, the new brand introduced by the Directive in the European single market in future will include two categories:

- the 'European Covered Bond', logo may be used (not obligatorily) by a covered bond that fully complies with the requirements of the Directive;

- the 'European Covered Bond (Premium)' logo may be used (not obligatorily) by a covered bond that meets all the requirements of the CRR Amendment.

One key area of cover regulation is the issue of collateral valuation. In this context, there is a uniform requirement for Member States to have a valuation standard agreed by experts in each Member State and to have a register suitable for recording the ownership and encumbrances of collateral assets, which is accessible to the public (in practice, this means an authentic public real estate and maritime registry).

As part of the cover pool, the Directive also defines two special cover assets, derivative contracts and liquid assets. The latter will be given high priority in the renewed regulation, because it considers liquidity risk mitigation to be crucial to ensure the protection of covered bond investors. In line with this regulatory objective, it will become mandatory for covered bond issuers to establish a liquidity buffer to cover the maximum cumulative net liquidity outflow over the next 180 days. ${ }^{1}$ The introduction of this new requirement is intended to address risks of

\footnotetext{
${ }^{1}$ According to Article 3(16) of the Directive "net liquidity outflow' means all payment outflows falling due on one day, including principal and interest payments and payments under derivative contracts of the covered bond programme, net of all payment inflows falling due on the same day for claims related to the cover assets".
} 
liquidity shortage, such as mismatches in maturities and interest rates, payment interruptions, commingling risks, payment obligations attached to derivative contracts and other operational liabilities falling due within the covered bond programme. Therefore, the liquidity buffer for the cover pool differs from the general liquidity requirements imposed on credit institutions in accordance with other Union legal acts, as the former is directly related to the cover pool and seeks to mitigate liquidity risks specific to it. In view of the parallel liquidity requirements for credit institutions, the Directive allows Member States not to enforce the cover pool liquidity buffer requirement in their regulations until the harmonisation of such rules. This way the credit institutions may avoid having to cover the same outflows with different liquid assets during the same period, but only if under its period of validity Union law imposes no other liquidity requirement on the credit institution.

In addition to the above, an essential part of the coverage regulation is the cover register, which is a key instrument for the implementation of both principles, the dual recourse principle and the bankruptcy-remoteness principle. Accordingly, the mandatory separation of cover assets from the issuer's other assets and their priority control by a cover pool monitor (as defined in the Hungarian legal system, 'asset controller') are important parts of the directive.

In addition to limiting the composition and the separate registration requirement of the cover pool, determination of the minimum level of coverage is another important scope of the collateral regulation of the Directive. It is important to note that Article 15(6) of the Directive (EU 2019a) provides a specific calculation rule only for aggregate principal amount, and only as a minimum rule when it states: "The calculation of the required coverage shall ensure that the aggregate principal amount of all cover assets is equal to or exceeds the aggregate principal amount of outstanding covered bonds ('nominal principle')". In addition, of course, the cover pool must provide coverage for the interest on the covered bonds in circulation, the payment obligations related to derivative contracts placed as collateral, as well as the expected maintenance and administration costs of the liquidation of the covered bond programme. However, no specific calculation rule for these items is laid down in the Directive, which Member States are entitled and obliged to define during implementation within the framework of the prudential requirements of the Directive. Although the overcollateralisation of covered bonds is now commonplace based on market experience, this expectation does not appear at the basic regulation level. However, as shown in Section 3.3, this is already a mandatory element in the regulation of the CRR Amendment, i.e. in the category of 'European Covered Bond (Premium)'. 
As an overview summary of the above rules, the set of cover assets representing the cover pool and the system of collateral assets in the regulation of the Directive are illustrated in Figure 2.

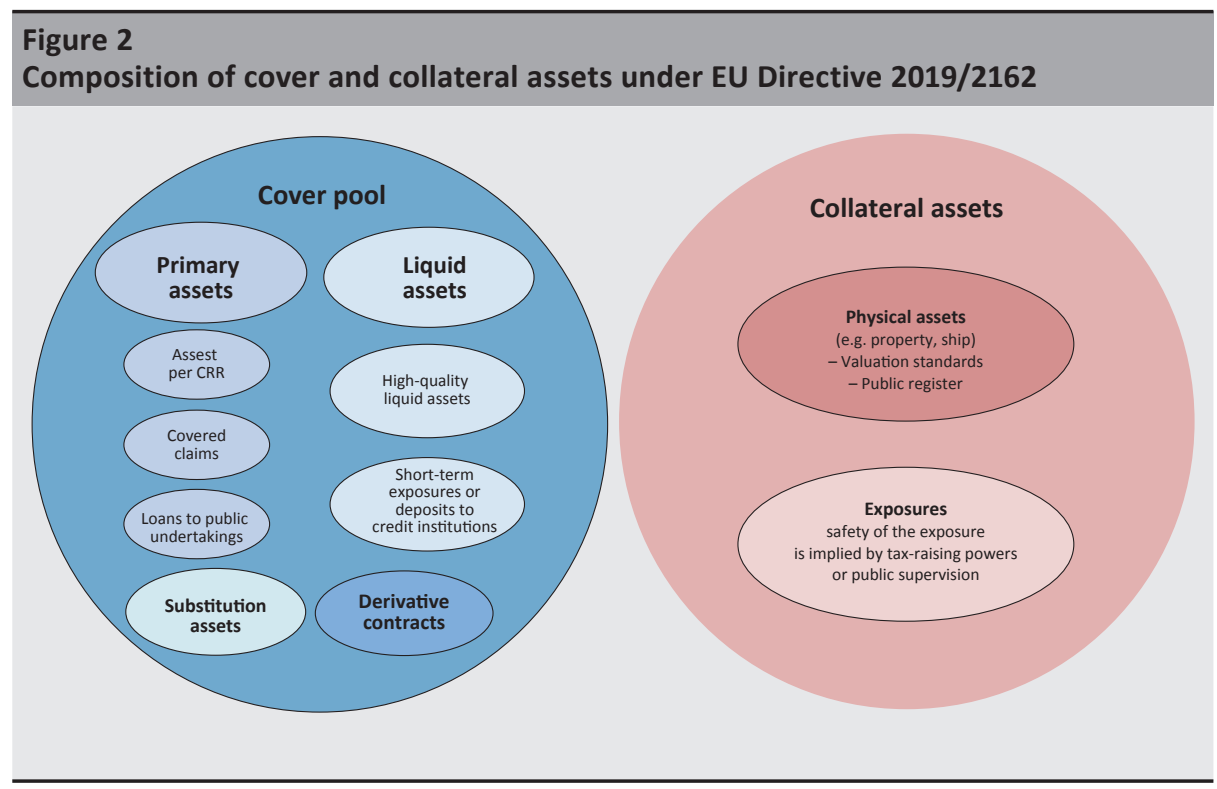

\subsubsection{Information for investors}

In order to facilitate informed investor decisions, credit institutions issuing covered bonds must provide information on their websites at least on a quarterly basis on, inter alia: the value of the cover pool and outstanding covered bonds, the geographical distribution and type of cover assets, their loan size and valuation method, the maturity structure of cover assets and covered bonds, the levels of required and available coverage, and the levels of statutory, contractual and voluntary overcollateralisation as well as the percentage of distressed loan or loans overdue for more than 90 days.

In addition to issuers, organisations supervising covered bonds are also required to provide information. An essential element of investor protection is to ensure that competent authorities publish regular information concerning the provisions of national law transposing the Directive and on the manner in which they perform their covered bond public supervision, in order to strengthen market confidence in covered bonds. 


\subsubsection{Public supervision of issuers}

The requirement for special public oversight of covered bond issuers was already a key element of covered bonds pursuant to Article 52(4) of Directive 2009/65/EC. The Directive considered it necessary to harmonise the components of such public oversight of covered bonds and to clearly define the roles and responsibilities of the national competent authorities responsible for financial supervision.

Public supervision of covered bonds is different from the EU supervision of credit institutions, accordingly, Member States are entitled to designate other national competent authorities responsible for the financial supervision of covered bonds, which may be different than the competent authorities responsible for the general supervision of the credit institution. The main task of financial supervision is to authorise the issuance of covered bonds by credit institutions (covered bond programme) and to protect the rights and interests of covered bond investors in the event of issuer insolvency or resolution proceedings, in cooperation with, but with clear separation from, the other competent authorities, by ensuring that the ongoing or reliable management of the covered bond programme is ensured during insolvency or resolution proceedings.

The Directive obliges Member States to provide for effective, proportionate and dissuasive administrative or criminal sanctions and to define procedural rules which give priority to the protection of the covered bond market, while respecting the protection of the interests of issuers.

\subsubsection{Highlights of implementation}

In addition to the topics highlighted in separate chapters, the domestic transposition of framework regulations defined at the EU level offers regulatory opportunities in several professional issues and requires regulatory adaptation, which can be matured in important and exciting professional discussions. In our view, the following issues deserve special attention:

a) Joint funding (Article 9 of the Directive): This model makes the issuance of a mortgage bond as a special security applicable to market conditions where the original loan operation and its collateral securitisation are separated. This regulation can be an excellent basis for the regulatory differences of the socalled refinancing model, which actually represents a significant part of Hungarian market practice, to be more pronounced, during which the current practice can be modernised. This regulatory approach fits well with the dual structure that currently exists in domestic regulation, i.e. simultaneously regulation of the direct financing ("OTP") model and the refinancing ("FHB") ${ }^{2}$ model;

\footnotetext{
${ }^{2}$ FHB Mortgage Bank Plc became member of the Takarék Group and was renamed to Takarék Mortgage Bank Co Plc.
} 
b) Range of institutions that can be refinanced (Article 9(3) of the Directive): The Directive offers Member States the possibility of extending the range of institutions that can be refinanced to non-credit institutions. This authorisation allows, for example, the mortgage loan portfolio of mortgage houses to be taken over as collateral, an option which, in our opinion, is not justified in the domestic environment, neither based on market conditions nor on the previous experience of recovering such portfolios;

c) Collateral protection in the event of issuer resolution (Article 12(2) of the Directive): The Directive sets out as a clear requirement for transposition in the Member States that the separation of mortgage bonds and thus their independence from the issuer must be ensured in both liquidation and resolution. This requirement imposes a task for domestic implementation, as collateral protection is currently not provided in the case of the resolution of mortgage credit institutions. In doing so, in our opinion, the scope and manner of extending the quite well-developed domestic regulations still valid for insolvency must be implemented with careful consideration;

d) Continuous high quality of cover assets (Article 15(4) of the Directive): Under the Directive expectation system, the inclusion of distressed loans as collateral is prohibited, which is completely absent from current Hungarian regulations. Jht. pays close attention to inclusion as collateral and imposes a number of strict, sometimes excessive requirements on a mortgage loan as to when it may become collateral, but does not set legal requirements for the period after inclusion as collateral. Thus, the development of domestic regulation can be considered an important task in this regard;

e) Renewal of the coverage supervisor institution (Article 13(3) of the Directive): The Directive provides an opportunity to consider whether a Member State should employ a coverage supervisor ('cover pool monitor' in the Directive's definition). According to this innovative approach, this important task should not necessarily be performed by a person separate from the credit institution and its auditor, but by ensuring direct financial supervision of the supervisory board, i.e. by enforcing the criteria governing internal control, an employee could also be entrusted with such a task. Taking into account the current practice experience, it is recommended to consider introducing this new option in Hungary as well, since ensuring this work within the organisation mainly as an administrative task, i.e. certifying the correctness and authenticity of the collateral register, can improve the efficiency of the mortgage credit institution. In this context, however, the assessment of investors and rating agencies should also be considered, but we 
believe that this should not be enforced in the scope of regulation in principle, but rather in the scope of practical application.

f) Extendable maturity structures (Article 17 of the Directive): The Directive has elevated the long-standing voluntary regulation on the European mortgage market into the legal framework, allowing Member States to have the so-called 'soft bullet'. According to this, a Member State may provide for the possibility of issuing a mortgage bond, the maturity of which could be extended to a predetermined extent in the event of the occurrence of objective events defined by law, independently of the discretion of the mortgage issuer. We recommend that this issue be considered during transposition of the Directive, taking into account further detailed conditions, since such an option suggested by the issuer may improve the rating of domestic mortgage bonds;

g) Match funding requirement (Article 3(15) of the Directive): This requirement is related to the regulation of the 'liquidity buffer' introduced by the Directive, which is of great importance in its effect as it results in an exemption from the formation of the buffer, but its regulation is by no means detailed: apart from the legal definition, it does not appear among the provisions of the Directive. It is known that it appears in EU legislation in view of the peculiarities of the Danish mortgage bond market, i.e. a perfectly synchronised system of mortgage bonds and mortgage loans. At the same time, we do not see any obstacles to its applicability in the case of the domestic refinancing model, which is detailed in Section 4.3.3.

\subsection{Main provisions of the CRR Amendment}

Article 129 of CRR (EU 2013) currently provides for the preferential treatment of covered bonds with regard to capital requirements, subject to certain conditions. Given that the Directive re-regulates the main elements of covered bonds and provides for a common definition of covered bonds, it has also become necessary to update the related prudential requirements. The fact and amount of the capital discount on exposures in the form of covered bonds is not affected by CRR Amendment (EU 2019b), but the following main modifications are set out as required conditions to benefit from this discount.

\subsubsection{Overcollateralisation (OC)}

In order to further improve the quality of covered bonds receiving preferential treatment, CRR Amendment (EU 2019b) makes such preferential treatment conditional on overcollateralisation, and thus the collateral level of the covered bond must exceed the coverage requirements set out in the Directive. The clear purpose of overcollateralisation is to mitigate the most significant risks in the event of the insolvency or resolution of the issuer. 
As a general rule, CRR Amendment (EU 2019b) sets an overcollateralisation level of 5 per cent, but Member States may set a lower minimum overcollateralisation level for covered bonds of at least 2 per cent if the calculation of the overcollateralisation is based on a formal approach that takes into account the underlying risk of the assets or valuation of assets is subject to the mortgage lending value.

\subsubsection{Loan-to-value ratio (LTV)}

To ensure the credit quality of covered bonds, limiting the loan-to-value ratio has so far been an essential element of regulation. The CRR Amendment ( $E U$ 2019b) does not change the current limits on the loan-to-value ratio, but CRR (EU 2013) does not specify how that ratio is to be applied. CRR Amendment ( $E U$ 2019b) clarifies that limits on the loan-to-value ratio should be applied as soft collateral limits, meaning that the size of the underlying loan is not limited, but all loans can only be accepted as collateral within the limits on the loan-to-value ratio of the related assets. Accordingly, the regulation clarified that the limits on the loan-to-value ratio determine the part of the loan that contributes to the coverage of the covered bond. As a further clarification, CRR Amendment states that the limits on the loanto-value ratio should apply to the entire term of the loan.

\subsubsection{Revaluation of collateral}

The requirements for assets that serve as collateral for covered bonds are related to the general quality characteristics that ensure the strength of the cover pool and are therefore set out in the Directive. Consequently, the provisions on the valuation method did not need to be formulated in a separate CRR requirement.

However, for the real estate collateral of covered bonds these must be monitored regularly and at least annually for all real estate. In the case of residential real estate where, as a general rule, real estate value monitoring has so far taken place every three years, this can be considered a significant and major change due to its large scale. Although some mortgage banks in Hungary already perform revaluations more often than every three years (using statistical methods), a rule of a general nature can help to improve the accuracy and automation of statistical methods, making them more widely available and more efficient.

\section{Revision of refinancing options during implementation}

\subsection{Basic principles}

Hungary is classified as a properly regulated country within the EU by the regulations set out in Jht. (1997), so no significant transformative impact of implementation is expected on the institutional and financial supervision structures. It is important, however, that in case of four out of the five mortgage banks, mortgage loan origination is no longer carried out by them, but their refinanced commercial 
banking partners. The activity of the mortgage banks is mainly limited to raising funds on the capital market and transferring the necessary long-term funds to the commercial banks.

In light of the above, transposition of the Directive should therefore seek, on the one hand, to maintain the existing, well-functioning framework and, on the other hand, to modernise domestic mortgage bond regulations in order to further improve market conditions and efficiency, taking advantage of the opportunities and special aspects offered by the Directive. Examining the details of the new regulation in accordance with these basic principles, in our opinion, the following areas deserve special attention during implementation.

\subsection{Challenges in the current refinancing system}

\subsubsection{Features of refinancing loans}

The unique structure of domestic mortgage bank refinancing can be described as follows:

- mortgage loans are provided by commercial banks to their own customers, on the basis of which they establish an independent mortgage lien on the collateralised real estate;

- keeping their mortgage loans on the balance sheet, the lender bank sells the individual mortgage liens registered in its favour to the refinancing mortgage bank, which purchases them for an amount not exceeding the outstanding principal of the secured loan covered by the lien;

- at the same time as the sale of the independent mortgage lien, the commercial bank enters into a reverse repurchase agreement with the mortgage bank, in which it agrees to repurchase the independent lien from the mortgage bank at least in instalments corresponding to the instalments which the customer is obliged to repay the mortgage loan to the commercial bank;

- the repurchase price of the independent mortgage lien is the claim of the mortgage bank against the commercial bank, secured by statutory assignment, due the mortgage bank according to Jht. (1997). Based on this, in the event of nonpayment or insolvency of a commercial bank, by the force of law the mortgage bank becomes the direct holder of the mortgage loans which it refinanced.

In the current Hungarian model, a transaction between a refinancing and a refinanced bank can be defined as low risk and therefore - as also recognised by CRR (EU 2013) $)^{3}$ - as a low-capital interbank loan, which is suitable for inclusion in the strict collateral system of mortgage bonds. In line with the regulatory interest

\footnotetext{
${ }^{3}$ See Article 402(3) of Regulation (EU) No 575/2013
} 
associated with the transfer of the state interest subsidy for housing being a decisive factor in its formation, the refinancing creates coherence at the micro level, i.e. at the level of each mortgage loan, between the refinanced and the refinancing transaction, in the interests of making the full amount of the state subsidy applicable through the issuance of covered bonds available to all borrowers. The consequence of the construction is that as the individual mortgage loans in the books of the commercial bank decrease month by month due to the continuous payment of principal, and the monthly partial repurchase of the independent lien in the books of the mortgage bank continuously reduces the repurchase price of the independent lien, which also results in continuous amortisation of coverage of a mortgage bond. Thus, in the model, the maturity and repayment schedule of the refinancing loans of the mortgage bank are inevitably linked to the refinanced loans. This creates a situation as if the refinancer were the direct lender, and thus portfolio-level management of refinancing is not supported by this structure. ${ }^{4}$ This feature also has a significant impact on the balance sheet structure of mortgage banks, as refinancing loans inevitably deviate from the maturity and repayment schedule of the mortgage bonds, thus generating risks in mortgage banks' balance sheets.

The legal framework for refinancing loans was significantly affected by the new Civil Code (Polgári Törvénykönyv 2013), which entered into force on 15 March 2014. Section 5:100 of this legislation introduced the institution of the so-called separate mortgage lien, replacing the independent mortgage lien. This substantial change in the lien rules had a beneficial effect on mortgage bank refinancing in that the liens based on real estate by the refinanced bank were no longer the subject of the refinancing (as a transaction item), but rather the collateral. This change made it possible to implement a business model in which the mortgage bank provides a portfolio refinancing mortgage loan to the refinanced bank in a 'collateralised interbank transaction', which separates the collateral for this credit operation from its real estate lien claims and transfers them to a mortgage bank. However, the institution of the separate lien could not play this role permanently in the domestic legal system, even though it was established precisely in view of mortgage banks' refinancing loan operations. The separation of the lien from the underlying transaction had the compelling consequence that the unconditional relationship between the debtor of the original loan and the mortgagor (ancillary to the lien at the time of formation) was terminated. This appeared to be a legal risk of double performance, i.e. the repayment of the debtor was not necessarily accompanied by the termination of the mortgagor liability, which is inherent in an independent lien as well, but could be better addressed in its regulatory framework.

\footnotetext{
${ }^{4}$ Portfolio refinancing is already present in the domestic market, during which the parties agree on a lump sum and pre-determined refinancing, but even in this case, the continuous amortisation of the repurchase price of individual liens must be managed through recurring lien sales.
} 
In view of this, and also due to the need to clarify the legal effects of the lien in liquidation proceedings, the separate lien was rescinded after about 2.5 years of operation. From October 2016, mortgage bank refinancing once again operated on the basis of an independent mortgage lien, with which the model resulting in the above detailed micro-level coordination has returned.

\subsubsection{Collateral scheme for refinancing loans}

The regulation of collateral assets in the Directive primarily applies to the default structure, i.e. in the case where the issuer of the mortgage bond is also the originator of the mortgage loan. In our opinion, the rules applicable to domestic conditions, which can be considered as exceptions, are contained in Article 9 of the Directive (EU 2019a) ('joint funding'), which allows the issuance to be co-financed by two or more credit institutions. In such a case, for the issuance of covered bonds by a credit institution, several credit institutions pool cover assets together in such a way that the lending bank sells the mortgage loan portfolio or transfers it to the issuing credit institution as collateral through a financial collateral arrangement ( $E C$ 2002). The aim of the Directive is also to make it possible to achieve the highest possible issuance volumes; therefore, according to the Beaumont (2019) report, a joint cross-border mortgage bond issuance programme has been launched for the Baltic countries as an experiment.

Both portfolio transfer techniques are already in force under Jht. (1997), since the purchase of portfolios by mortgage banks, as well as refinancing in addition to the transfer of bank portfolios as collateral are also regulated events. From this practice, the dominant solution is the transfer as collateral: the collateral of the refinancing resources provided by the domestic mortgage banks is the assignment of the refinanced mortgage loans. ${ }^{5}$ This collateral position is vested in mortgage banks as provided by law. Therefore, if the refinanced bank breaches any of its payment obligations to the mortgage bank resulting from the refinancing, with or without the MNB initiating its liquidation, the assignment will take place under the law, thus making the mortgage bank a direct creditor of the mortgage loan transactions it has refinanced thus far. Based on the value of the portfolio thus taken over and the amount of the debt from the refinancing, a settlement obligation arises between the parties, during which the net value of the portfolio (reduced by impairment, approved by an auditor) can be taken into account. In order to minimise possible mortgage bank losses during such a settlement, it is a legal requirement that the amount of the refinancing loan may never exceed the amount of the refinanced loan. ${ }^{6}$ On this basis, we consider that the current regulation can be implemented in accordance with Article 9 of the Directive, and so in this respect transposition does not necessarily result in a need for amendment. However, with regard to

\footnotetext{
${ }^{5}$ See Section 8(6) of Jht.

${ }^{6}$ See Section 8(5) of Jht.
} 
assignment, it is worth examining its efficiency in more detail. One of the most important critical findings is that the statutory assignment does not create a legal succession for each loan agreement, only for the claims arising from it, so it would be appropriate to apply the contract transfer rules. However, even in the case of this necessary rule change, it becomes mandatory to include individual mortgage loans in the mortgage bank balance sheet when the conditions occur, during which the requirements expected by the $M N B$ (2020) cannot be met as follows:

- due to the collateral nature, the portfolio must be taken over even if the own funds requirement and the business plan for its management (pursuant to Credit Institutions and Financial Enterprises Act (Hpt. 2013), these two are separate conditions for the authorisation of a portfolio transfer) are not provided by the mortgage bank;

- in the case of mortgage banks operating in purely refinancing models, no actual mortgage loan and related workout takes place, so typically neither banks' IT systems nor its organisational conditions are prepared for such a takeover;

- in the process, consumer protection guarantees cannot be enforced, as both the mortgage bank and the parties concerned only become aware of the date of the assignment $^{7}$ after the fact. In this case, the right of borrowers to terminate the contract free of charge, and even the right to prior information, cannot prevail in the face of unavoidable unilateral contract amendments.

\subsubsection{Implementing overcollateralisation}

With respect to structured securities, Fabozzi et al. (2006) define overcollateralisation as essentially an internal credit enhancement mechanism based on the principle that the value of collateral assets that cover securities exceeds the value of the securities. With this structure, it is possible to prepare for the situation that one or a few individual loans go bankrupt behind a security, while the remaining collateral assets (additional loans) can still provide bondholders with timely interest and principal payments.

However, in the pooling model, the above risk typically appears differently. The refinanced commercial bank may have to repurchase the defaulting individual customer loans from the mortgage bank and replace them with new ones. Thus, from the credit risk point of view, the pooling model can be considered safer for mortgage bondholders, since in the case of direct lending, the credit loss arises directly in the balance sheet of the mortgage bank, whereas in the pooling model the loss appears in that of the commercial bank. This is more advantageous for

\footnotetext{
${ }^{7}$ According to Section 8(6) of Jht., the date of assignment is "the date of submission of the application for liquidation to the court", which can be known only when the order initiating the liquidation proceedings is published.
} 
the mortgage bank and for the commercial bank for the same reasons: the capital market providing the ultimate funding will continue to fund an impeccable quality mortgage portfolio, so the capital market investor will determine the funding costs accordingly.

It is also important to note that, in contrast to a 'classic' securitisation, where a 'seemingly risk-free' transaction (Marsi 2008:488) can be established, according to the 'originate to distribute' model presented by Király - Nagy (2008), the pooling model also encourages commercial banks to restrain themselves. The reason for this is that even if a commercial bank places 'doubtful' mortgage loans in the mortgage bank collateral pool, no actual transaction occurs, so they will not be mortgage bank assets, and it may even have a repurchase obligation to the mortgage bank on the day it becomes a distressed loan. The stock of non-performing loans thus appears on the balance sheet of the original creditor commercial bank, motivating them to adopt more prudent lending practices.

However, overcollateralisation is currently expected by the credit rating agency, even in the case of the appropriate orientation of the interest schemes summarised above, and in the future the legislator, as summarised in Section 3.3.1.

In the case of 'Joint funding' as presented in Section 3.2.4, the Directive (EU 2019a) offers the possibility for assets to be transferred between partners through a collateral agreement, and accordingly - similar to the current domestic refinancing mortgage banking operation - the original loan remains on the lender balance sheet and the mortgage bank should 'only' acquire collateral entitlement. For this type of portfolio takeover, the fundamental issue is to assess whether the assets taken over should be considered as cover assets or collateral for the issued mortgage bonds. If they can be considered as cover assets, they can also be considered as overcollateralisation, while if they can be identified as collateral assets, they cannot be taken into account in meeting the cover level of the mortgage bonds. Arguments can be made for and against both positions on this fundamental issue of interpretation, but in our interpretation, in the case of joint funding, these assets taken over by the issuer can be considered as collateral for covered bonds. The correctness of this interpretation is reinforced by the reasoning in Preamble Paragraph (21) of the Directive that states: "That would provide for the pooling of cover assets by several credit institutions as cover assets for covered bonds issued by a single credit institution...".

In the case of refinancing, the current regulation of Jht. (1997) considers only the claim against the refinanced bank as ordinary coverage for mortgage bonds; it interprets the mortgage loan portfolio taken over from the refinanced bank as collateral assets. However, this regulation has the serious disadvantage that no matter how much the refinanced bank increases the assets it transfers, that is, to 
whatever extent it exceeds the amount of mortgage loans transferred as collateral the refinancing capital received, they cannot result in overcollateralisation by the issuer, as they do not directly qualify as collateral for mortgage bonds. For this reason, purely refinancing mortgage banks, during their normal course of operations, are unable to meet the overcollateralisation from mortgage loans disbursed by the refinanced partner bank, they must also use additional capital to cover overcollateralisation, even if the refinanced bank has already effectively provided overcollateralisation with the 'surplus' mortgage loan provided as collateral. The additional capital, by its nature, cannot be low-cost mortgage bonds funding, but can only be raised from equity and/or as unsecured capital, making it more costly. In this way, the current domestic operating environment generates unjustified additional costs on the part of mortgage banks, thus making mortgage loans more expensive.

\subsection{Opportunities to improve efficiency}

\subsubsection{An alternative to refinancing loans}

In connection with the MFAR regulation, there is a realistic need between mortgage banks and refinanced institutions for refinancing to take place at the portfolio level, i.e. the refinanced institution should receive a lump sum of long-term funding from the mortgage bank, with which the actual lenders manage their long-term funding needs at the portfolio level. The efficiency of such an interbank loan can be significantly improved if the legislator does not expect the purchase and repurchase of individual independent liens, but allows the provision of so-called refinancing mortgage loans. This concept is already known in Jht. (1997) regulation, as the legislator has previously defined the activities of mortgage banks as an interbank loan when regulating refinancing with separate lien collateral. This notion should be corrected to the extent that, in the renewed refinancing mortgage loan regulation, the collateral for this loan, as described in Section 4.3.2, could be the mortgage right of the refinanced loans (as receivables).

With regard to this proposed new refinancing item, it should be noted that the only exception to the 'Large Exposures' regulated in Part Four of CRR (EU 2013) is refinancing through the transactions of independent liens. ${ }^{8}$ Due to this regulation, the new model may be an efficient method of refinancing any bank by complying with the large exposure limits, and by ignoring these limits, refinancing can work within the banking group without taking into account the large exposure limits, if the exemption for large exposures under Article 400(2)(c) of CRR (EU 2013) ${ }^{9}$ can

\footnotetext{
${ }^{8}$ See Article 402 (3) of CRR.

${ }^{9}$ (Competent authorities may fully or partially exempt the following exposures:) " $c$ ) exposures, including participations or other kinds of holdings, incurred by an institution to its parent undertaking, to other subsidiaries of that parent undertaking or to its own subsidiaries, in so far as those undertakings are covered by the supervision on a consolidated basis to which the institution itself is subject, in accordance with this Regulation, Directive 2002/87/EC or with equivalent standards in force in a third country;"
} 
be applied in the banking group concerned. However, as the proposed new model is fully equivalent to the current model in terms of risk-taking content and is an issue that is also relevant at the EU level as an impact on the transposition of the Directive, it seems justified to initiate a correction of the CRR regulation, which may become a realistic option in view of it entering into force on 8 July 2022.

\subsubsection{An alternative to the refinancing collateral system}

The dilemmas explained earlier raise the basis for renewing collateral rules in refinancing. Based on the relevant provisions of the EU (EC 2002) and the Civil Code (Polgári Törvénykönyv 2013), it may be suitable collateral for refinancing the lien on refinanced claims secured by real estate mortgages. In the course of this new collateral regulation, similarly to the current assignment rules of Jht. (1997), it is still justified to establish these mortgage rights not by contract, but by legal provision on the basis of the Civil Code, however, the establishment of such also requires entry in the collateral register. Mortgage rights based on this claim may also be registered with circumscription in accordance with the Civil Code, that is, it shall not be recorded separately for each mortgage loan transferred as collateral, but for all mortgage loans created in the course of refinancing cooperation. In order for this legal solution to be appropriate, it needs to be clarified whether a claimbased mortgage can be properly established for the future at the start of refinancing cooperation, as it would provide a workable structure for a mass pledge of mortgage claims and thus for efficient refinancing. Futurity should be examined in terms of both the refinancing loan, i.e. the collateral claim, and the mortgage claim given as collateral, as in the ideal model neither exists at the time of registration. With regard to the secured claim, we consider the position, based on Section 5:89(5) ${ }^{10}$ of the Civil Code, that: "... a lien is created even if, at the time of the conclusion of the lien, the contractual relationship from which the future claim arises does not yet exist. However, the claim or the legal relationship must be identifiable in some way in this case as well. [...] This means that at least the subjects and title of the fundamental relationship (e.g. loan) must be known. (Bodzási 2015:555). We also share the view that "Future claims may be secured not only by a contractual lien but also by a legal lien." (Bodzási (2015:556). The futurity of mortgage claims provided as collateral is also not an obstacle to the proposed pledge, as according to Vékás - Gárdos (2014): "In the case of a mortgage based on moveable things, rights and claims [...] due to the nature of these assets and the nature of the collateral register, the mortgage may be registered even if the pledged property does not exist, it is not owned by the mortgagor, or the mortgagee does not otherwise have the right of disposal over it (Section 5:112). Therefore, in connection with the existence of a lien,

10 "The claim secured by lien shall be specified in a manner allowing it to be identified by making a reference to the underlying legal relationship or relationships and by specifying the amount, or by any other way allowing the identification of the secured claim. The specification may also include a claim that has not yet been established." 
in the event of a dispute, the question to be examined independently is whether the mortgagor was the owner of the given property. If this condition is not met, the lien may not be created, notwithstanding the completion of the underlying transaction. However, it is not necessary for this condition to exist when the lien is established; a mortgage may be established in respect of things to be acquired in the future, with the exception of immovable property and other registered property, and the lien shall also be created if the mortgagor acquires title to the lien after the lien has been established."

On this basis, well-functioning collateral legislation can be established, where the refinanced bank would create a mortgage loan based on a claim under Jht. (1997) for mortgage loans offered to the mortgage bank as collateral for the entire duration of the refinancing cooperation, which may be entered in the collateral register by circumscription for each refinanced bank on the basis of a refinancing cooperation agreement, even before the commencement of refinancing. This collateral structure may have the following significant benefits:

- By entering the claim-based mortgage into the collateral register, by the force of law under Jht. (1997), in respect of a mortgage on immovable property established as security for a pledged claim, a sub-lien is created in favour of the mortgage bank. The creation of this sub-lien does not require the conclusion of a separate lien agreement or the transfer of a lien in the case of an independent lien, the lien is created as a legal lien in favour of the mortgage bank;

- Unlike assignment, when the lien is opened, i.e. in the event of non-payment, insolvency or resolution of the refinanced bank, the pledgee mortgage bank does not need and cannot have the collateral, that is, to acquire ownership of the receivables, i.e. there is no need to carry out a complicated transfer process;

- Instead of the immediate settlement obligation that accompanies the assignment, that is, when the net value of the stock taken over by the mortgage bank as a buyer at the time of takeover has to be compared with the amount of the receivable from the refinancing, which may result in a loss, the current net value of the pledged mortgage loan in favour of the mortgage bank does not have to be examined at the opening of the lien and there is no prompt settlement obligation, so the risk of loss can be reduced.

\subsubsection{Mortgage bond collateral system}

To address the dilemma of the mortgage bond collateral system, we examined several European mortgage bond markets, which are presented in the most comprehensive way by Kemmish et al. (2017). We found the largest non-EU mortgage bond market, the Swiss market, which was about EUR 119 billion at the end of 2018, according to Kullig et al. (2019), to be the most efficient and simple, and thus, for the sake of illustration, clear and understandable (Figure 3). 


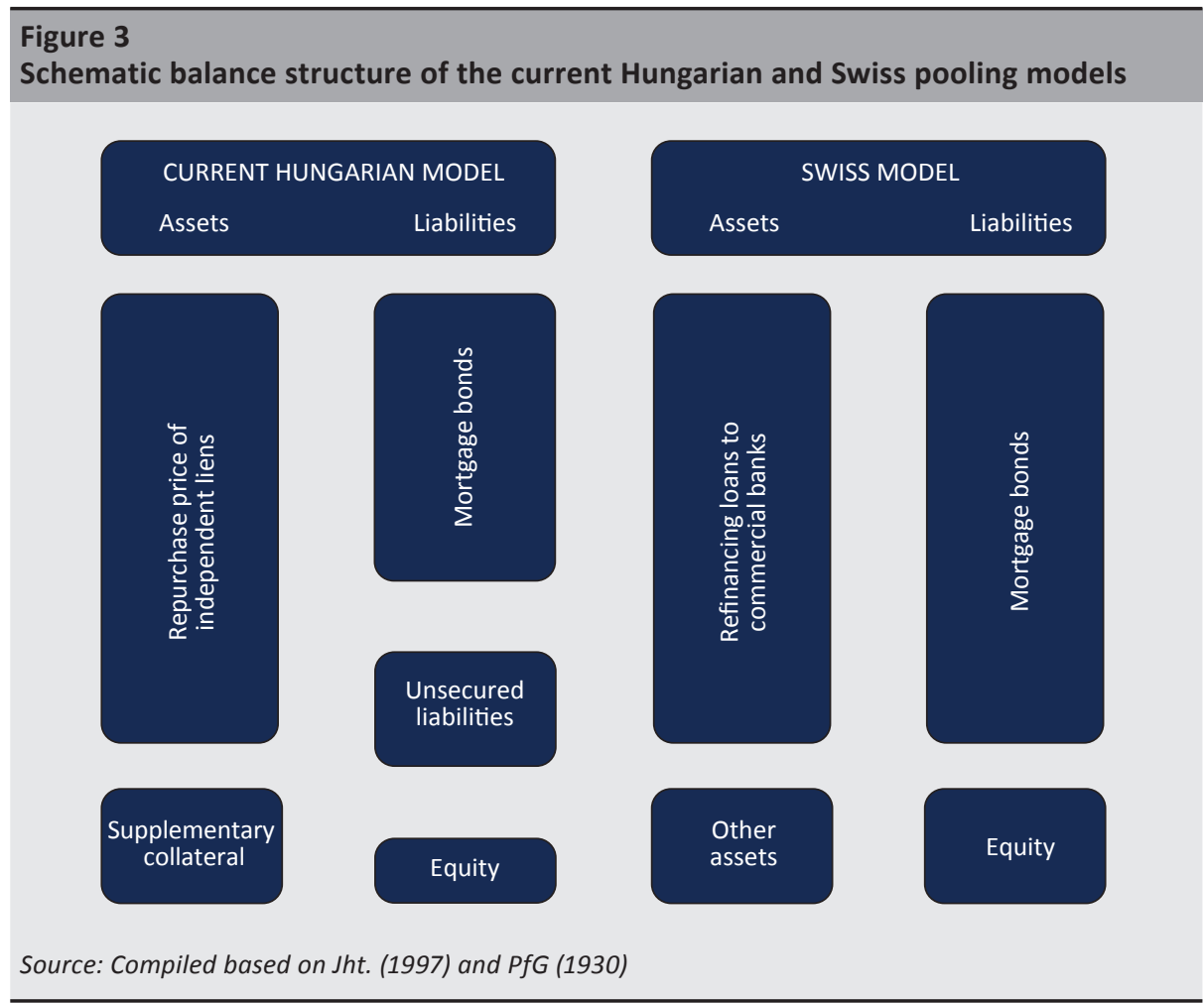

In Switzerland, only mortgage banks operating according to the pooling model can issue a Pfandbrief, which is a protected mortgage bond brand.

According to the summary of Bossert (2008), a Pfandbrief in Switzerland is covered by a refinancing loan and collateralised by a lien on a commercial bank mortgage loan, which ensures that in the event of non-payment by a commercial bank, loans to customers are removed from the commercial bank insolvency estate and transferred to the mortgage bank.

Literally interpreting the concepts of cover and collateral, the Swiss solution thus means that the mortgage bond cover is the refinancing loan granted, while the collateral of a mortgage bond is the pledged mortgage loan. Overcollateralisation means that there must always be more pledged mortgage loans on the mortgage bank records than refinancing loans (Figure 4). This system allows for free-of-charge 'OC' generation (there is no need to buy government bonds or supplementary cover from expensive, unsecured funding or even more expensive capital). It is important to emphasise, however, that the ' $\mathrm{OC}^{\prime}$ created in this model does not consist of the assets on the issuer balance sheet, but of the assets transferred to it as collateral, 
i.e. it results in off balance sheet overcollateralisation, on the other hand, the requirement for overcollateralisation is that the overcollateralisation provides added value in the event of the insolvency of the issuer, which in the current domestic regulation means overcollateralisation within the mortgage bank balance sheet. For this reason, the question arises as to whether a purely refinancing mortgage banking model based on the Swiss model can provide investor protection even in the event of a mortgage banks insolvency, since in the event of a mortgage bank bankruptcy where the commercial bank performs properly, the overcollateralisation instruments would not be available to mortgage bond investors.

However, another element of the examined Swiss model provides a solution to this. According to PfG (1930), the asset side of the mortgage bank balance sheet consists exclusively of refinancing, secured interbank loans, while the liability side consists exclusively of mortgage bonds (excluding the bank equity and its investment in liquid assets in a regulated manner). These loans, also according to PfG (1930), are obligatorily harmonised with the mortgage bonds in their maturity and amount, so that the mortgage bank is essentially market risk free. And by meeting these two criteria, the regulatory environment guarantees that the mortgage bank alone will not become insolvent towards mortgage bond investors, as this would only happen if a refinanced bank goes bankrupt. In this case, however, the liens would already be open in respect of the collateral, i.e. the pledged mortgage loans, taken into account in the context of the overcollateralisation, that is, these collateral would already cover the mortgage bonds of the mortgage bank.

Switzerland, as a non-EU Member State, is not part of the European banking regulatory framework, but given the high quality they represent, its regulatory principles and operational experience should be taken into account during implementation. However, the framework is broad enough for a similar system to work in the EU. For example, the Finnish legislation (KLPL 2010, in English: CBA 2010 ) is familiar with the concept of 'intermediary credit', which is a mortgagebacked credit granted by a mortgage bank. According to Section 16 of CBA (2010), the total amount of mortgage loans offered by the debtor of the 'intermediary credit' to cover the mortgage bonds must always exceed the principal amount of the 'intermediary credit'. This is equivalent in nature and operation to the operating principle of the Swiss pooling model. In the case of the Finnish example, according to Section 12 of CBA (2010), only mortgage loans, loans to the public sector or supplementary collateral can be used as collateral for mortgage bonds, so it is necessary to separate them from the 'intermediary credit' which is in the balance sheet. 
We deem the regulatory principle explained above presented with the almost 'laboratory-clean' Swiss example and reinforced by the Finnish example within the EU, worthy of consideration during implementation and elaboration in the framework of professional discussions covering the detailed rules. The definition of 'match funding requirements' in the Directive and the related legislation provide an appropriate basis for this. As a result of the innovative regulation, it would simply be sufficient to create overcollateralisation for mortgage loans financed by a covered bond once. It is important to emphasise, however, that such a regulatory step could not even potentially lead to a devaluation of mortgage bonds, and therefore, with key financial supervision, we see this overcollateralisation principle as feasible for mortgage banks that meet all the requirements of the model. To this end, from a regulatory and authorisation/supervisory point of view, we clearly recommend distinguishing between purely refinancing mortgage banks and mortgage banks that also carry out their own lending, which may be subject to different rules on certain issues, including overcollateralisation. In our opinion, the legal requirements for the status of a 'purely refinancing mortgage bank' (asset and liability side restrictions and their mandatory harmonisation) can be laid down in the new regulation, the fulfilment of which requirements would be established by the MNB as a licensing authority in a separate official licensing procedure, and it would be obliged to monitor its continuous fulfilment. In addition to the model that has worked well thus far and will be preserved in the future, this solution would create an alternative that could serve the development of the domestic mortgage bond market by ensuring the collateral security of mortgage bonds at the same level as at present, strengthening investor confidence.

\section{Figure 4}

The fourfold chain of security of the mortgage bond investor in the proposed new model

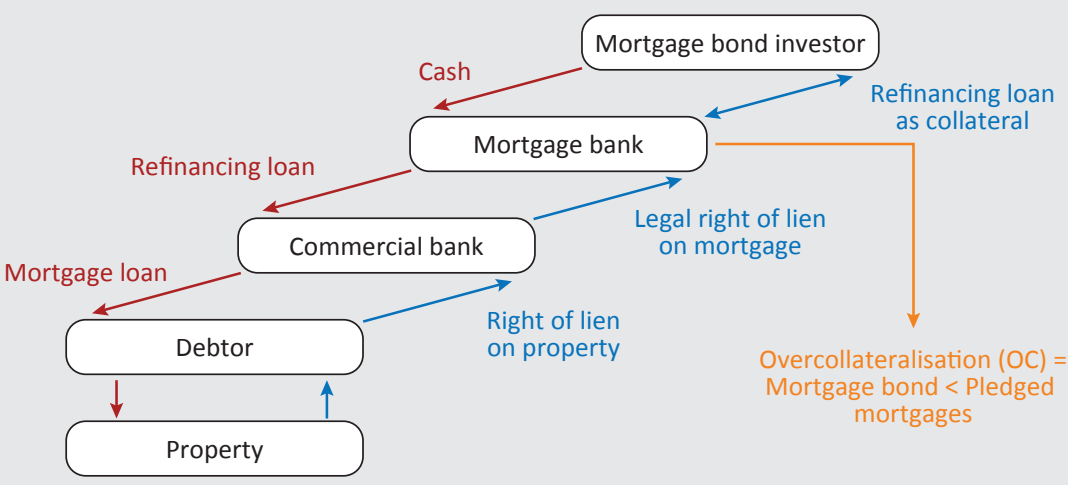

Source: Compiled based on Bossert (2008) p. 3 and legal adaptation 


\section{Summary}

With a detailed analysis of the new Directive and the related CRR Amendment and using the practical experience of the domestic model, we came to the conclusion that an alternative refinancing model can be defined during the implementation within the framework of Jht. in Hungary, which, while maintaining the current wellfunctioning model, can be summarised as an optional alternative, as follows:

- commercial lending operation by a refinancing mortgage bank: the provision of a refinancing mortgage loan to a credit institution that has a cooperation agreement with it and carries out mortgage loan activities for its customers;

- collateral for refinancing mortgage loans is the mortgage rights of mortgage loans granted by a refinanced credit institution that fully comply with the CRR Amendment and the requirements for cover assets set out in the Directive, which mortgage encumbering a claim is established by Jht. as a statutory lien in favour of the mortgage banks and which is entered in the collateral register by circumscription. The opening of this lien should be mandatory not only for nonpayment of the mortgagor, but also for insolvency or resolution proceedings.

The above-mentioned alternative model to refinancing may be suitable for the efficient execution of refinancing already at the moment of its introduction, with the restriction that it can operate between institutions outside the banking group within the limits of the large exposure limit, within the banking group without this restriction. In the refinancing area of non-banking group institutions, the new model would be a transaction with exactly the same risk as the current model defined as an exception currently under CRR (EU 2013), so we believe that a CRR amendment could be initiated to extend the individual exception to large exposures.

Another important conclusion of the study is that in the case of a purely refinancing mortgage bank, it is possible to specifically regulate the mortgage bond collateral system, necessarily taking into account the specific features of this model, especially the fact that the issuing mortgage bank is a special intermediary which securitises the mortgage loans of its partner banks with long-term mortgage bonds in favour of those banks. In the current operating environment, refinancing mortgage banks are not able to create overcollateralisation from their ordinary coverage during normal operation, and therefore, for reasons of cost-effectiveness, it is justified to examine the possibility of legislative corrections. Thus, in purely refinancing mortgage banks, the securitisation of refinanced credit institution assets, even if not in the refinancing mortgage bank balance sheet, but in the collateral registry there is an overcollateralisation, which can guarantee a high level of investor security. Accordingly, in such mortgage banks, which can be defined as a separate subtype, it is appropriate to regulate the mortgage bond collateral system in two 
layers, where the first layer is the assets appearing in the mortgage bank balance sheet (mainly refinancing mortgage loans), against which the legal requirement must be at all times at least equal to the nominal value of the mortgage bonds in circulation. The second collateral layer is the refinancing mortgage loans collateral, i.e. pledged mortgage loan by a refinanced bank or mortgage loan that is handed over by assignment, the resulting principal and interest claims of which must exceed the principal and interest amount of the refinancing mortgage loans to the extent required by the overcollateralisation requirement. In such a new model, we consider it a guarantee element that the risk of insolvency of the issuing mortgage bank is minimised, which can be determined in the mandatory reconciliation of refinancing loans granted and mortgage bonds issued and in the supervisory control of these requirements.

\section{References}

Beaumont, J. (2019): Covered bond harmonisation: a milestone reached. European Covered Bond Council. https://hypo.org/ecbc/publication-news/covered-bond-harmonisation-amilestone-reached-2/. Downloaded: 5 March 2020.

Bodzási, B. (2015): Feltételes vagy jövőbeli követelések zálogjoggal való biztosítása (Contingent or future claims secured by a lien). Magyar Jog (Journal of Hungarian Law), 62(10): 549-556.

Bossert, A. (2008): Swiss Pfandbrief - Rock solid. Credit Suisse Swiss Institutional Credit Research. https://pfandbriefbank.ch/sites/de/assets/File/Research_ Berichte/20080613\%20Swiss\%20Pfandbrief\%20-\%20Rock\%20solid\%20(Credit\%20 Suisse\%20AG).pdf. Downloaded: 2 March 2020.

CBA (2010): Covered Bond Act (688/2010, CBA). Finnish Covered Bond Act. http://www.ecbc. eu/legislations/15/CBA+688_2010+English+translation.pdf. Downloaded: 12 July 2020.

EC (2002): Directive 2002/47/EC of the European Parliament and of the Council of 6 June 2002 on financial collateral arrangements. https://eur-lex.europa.eu/legal-content/EN/ ALL/?uri=CELEX:32002L0047. Downloaded: 6 March 2020.

EC (2009): Directive 2009/65/EC of the European Parliament and of the Council of 13 July 2009 on the coordination of laws, regulations and administrative provisions relating to undertakings for collective investment in transferable securities (UCITS). https://eur-lex. europa.eu/legal-content/EN/TXT/?uri=CELEX:32009L0065. Downloaded: 26 February 2020.

ESRB (2012): Recommendation of the European Systemic Risk Board (ESRB/2012/2) on funding of credit institutions https://op.europa.eu/en/publication-detail/-/ publication/444654c7-acc9-11e2-ab01-01aa75ed71a1. Downloaded: 1 March 2020. 
EU (2013): Regulation (EU) No 575/2013 of the European Parliament and of the Council of 26 June 2013 on prudential requirements for credit institutions and investment firms and amending Regulation (EU) No 648/2012 https://eur-lex.europa.eu/legal-content/EN/ TXT/?uri=CELEX:32013R0575. Downloaded: 13 December 2019.

EU (2017): Regulation (EU) 2017/2402 of the European Parliament and of the Council of 12 December 2017 laying down a general framework for securitisation and creating a specific framework for simple, transparent and standardised securitisation, and amending Directives 2009/65/EC, 2009/138/EC and 2011/61/EU and Regulations (EC) No 1060/2009 and (EU) No 648/2012 https://eur-lex.europa.eu/legal-content/EN/ TXT/?uri=CELEX:32017R2402. Downloaded: 7 March 2020.

EU (2019a): Directive (EU) 2019/2162 of the European Parliament and of the Council of 27 November 2019 on the issue of covered bonds and covered bond public supervision and amending Directives 2009/65/EC and 2014/59/EU. https://eur-lex.europa.eu/legalcontent/EN/TXT/?uri=CELEX:32019L2162. Downloaded: 27 January 2020.

EU (2019b): Regulation (EU) 2019/2160 of the European Parliament and of the Council of 27 November 2019 amending Regulation (EU) No 575/2013 as regards exposures in the form of covered bonds https://eur-lex.europa.eu/legal-content/EN/ TXT/?uri=CELEX:32019R2160. Downloaded: 27 January 2020.

Fabozzi, F.J. - Davis, H.A. - Choudhry, M. (2006): Introduction to Structured Finance. 1st ed. Hoboken, John Wiley \& Sons, New Jersey.

Fóriánné Horváth, M. (2019): Jelzálog-hitelintézetek (Mortgage Banks). In: Kovács, T. (ed.): Pénzügyi intézményrendszer Magyarországon 2019. University of Sopron Press, Sopron, pp. 131-159. https://doi.org/10.35511\%2F978-963-334-336-4\%2FForianne_131-159

Hpt. (2013): 2013. évi CCXXXVII. törvény a hitelintézetekröl és a pénzügyi vállalkozásokról (Act CCXXXVII of 2013 on Credit Institutions and Financial Enterprises). https://net.jogtar. hu/jogszabaly?docid=a1300237.tv. Downloaded: 15 February 2020.

Jht. (1997): 1997. évi XXX. törvény a jelzálog-hitelintézetröl és a jelzáloglevélröl (Act XXX of 1997 on Mortgage Loan Companies and on Mortgage Bonds). https://net.jogtar.hu/ jogszabaly?docid=99700030.tv. Downloaded: 15 February 2020.

Kemmish, R. - Wilkinson, C. - Andruszkiewicz, O. (2017): Covered Bonds in the European Union: Harmonisation of legal frameworks and market behaviours. European Union. http://dx.doi.org/10.2874/49580

Király, J. - Nagy, M. (2008): Jelzálogpiacok válságban: kockázatalapú verseny és tanulságok (Mortgage markets in crisis: risk-based competition and lessons learned). Hitelintézeti Szemle, 7(5): 450-482. 
KLPL (2010): Laki kiinnitys/uottopankkitoiminnasta (KLPL) 688/2010. https://www.finlex.fi/ fi/laki/alkup/2010/20100688. Downloaded: 12 July 2020.

Kovács, Gy. (2004): A jelzáloglevél-kibocsátáson alapuló hitelezés problémái történeti megközelitésben (Mortgage bond-based lending problems in a historical approach). In: Botos, K. (ed.): Pénzügyek a globalizációban (Finances in globalization). Szeged: JATEPress, pp. 110-136.

Kullig, S. - Westig, D. - Bertalot, L. - Vazitari, C. - Johnson, J. - Garrido, S. (2019): ECBC: European Covered Bond Fact Book 2019. European Mortgage Federation-European Covered Bond Council, Brussels.

Marsi, E. (2008): Elmélkedés a subprime egyes jelenségeiröl (Reflection on some phenomena of the subprime). Hitelintézeti Szemle, 7(5): 483-490.

MFAR (2015): 20/2015. (VI. 29.) MNB rendelet a hitelintézetek forint lejárati összhangjának szabályozásáról (MNB Decree No. 20/2015 (VI. 29.) On the Regulation of the Forint Maturity Matches of Credit Institutions). https://net.jogtar.hu/jogszabaly?docid=a1500020. mnb. Downloaded: 18 February 2020.

MNB (2015): Jelzáloglevelek kibocsátásával válik biztonságosabbá a finanszírozás (By issuing mortgage bonds, financing becomes more secure). Magyar Nemzeti Bank press release. https://www.mnb.hu/sajtoszoba/sajtokozlemenyek/2015-evi-sajtokozlemenyek/ jelzaloglevelek-kibocsatasaval-valik-biztonsagosabba-a-finanszirozas. Downloaded: 10 March 2020

MNB (2016): Macroprudential report - October 2016. Magyar Nemzeti Bank. https://www. mnb.hu/letoltes/makroprudencialis-jelentes-en.pdf. Downloaded: 10 March 2020.

MNB (2017): Macroprudential report - December 2017. Magyar Nemzeti Bank. https:// www.mnb.hu/letoltes/makroprudencialis-jelentes-eng.pdf. Downloaded: 10 March 2020.

MNB (2018): Macroprudential report - 2018. Magyar Nemzeti Bank. https://www.mnb.hu/ letoltes/mnb-macroprudential-report-2018.pdf. Downloaded: 10 March 2020.

MNB (2020): Vezetői körlevél a pénzügyi intézmények közötti állományátruházás, a pénzügyi intézmények egyesülése és a pénzügyi intézmények alapvető informatikai rendszereinek cseréje esetén elvárt prudenciális, fogyasztóvédelmi és informatikai elvekröl (Executive Circular on prudential, consumer protection and IT principles expected in the case of transfers of funds between financial institutions, mergers of financial institutions and exchanges of basic IT systems of financial institutions). Magyar Nemzeti Bank, Budapest. https://www.mnb.hu/letoltes/vezetoi-korlevel-20200212.pdf. Downloaded: 4 March 2020.

PfG (1930): Pfandbriefgesetz. https://www.admin.ch/opc/de/classified-compilation/19300030/index.html. Downloaded: 27 May 2020. 
Papp, M. (2005): A jelzáloglevél alapú finanszírozás helyzete Magyarországon pénzügyi stabilitási szempontból (Mortgage bond financing in Hungary from the view of financial stability). MNB Múhelytanulmány 36, Magyar Nemzeti Bank.

Polgári Törvénykönyv (2013): 2013. évi V. törvény a Polgári Törvénykönyvröl (Act V of 2013 on the Civil Code). https://net.jogtar.hu/jogszabaly?docid=a1300005.tv. Downloaded: 15 February 2020.

Stöcker, O. (2011): Covered bond models in Europe: fundamentals on legal structures. Housing Finance International, Winter 2011, pp. 32-40. https://www.housingfinance. org/wp-content/uploads/2020/03/HFI-4-2011.pdf. Downloaded: 22 November 2019.

Tóth, T. (2017): Covered Bonds. MNB Handbooks No. 13, Magyar Nemzeti Bank pp. 1-40. https://www.mnb.hu/letoltes/mnb-oktata-si-fu-zetek-13-eng-0103.pdf. Downloaded: 4 March 2020.

Vékás, L. - Gárdos, P. (2014): Kommentár a Polgári Törvénykönyvhöz: Kommentár a Polgári Törvénykönyvröl szóló 2013. évi V. törvényhez (Commentary on the Civil Code: Commentary to Act V of 2013 on the Civil Code). Wolters Kluwer.

Vincze, J. (2002): A jelzáloglevelek piaci helyzete és fejlődési irányai (Mortgage bonds market situation and development trends). Hitelintézeti Szemle, 1(3): 61-80. 